Research Article

\title{
Factors Influencing the Adoption of ICT'S in Extension Service Delivery Among the Extension Agents in North-East, Nigeria
}

\author{
Saadu Mustapha ${ }^{1,2}$, Norsida Man ${ }^{1 *}$, Jasmin Arif Shah ${ }^{1}$, Nitty Hirawaty Kamarulzaman ${ }^{1}$ and Ahmadu \\ AbubakarTafida ${ }^{3}$
}

${ }^{1}$ Universiti Putra Malaysia (UPM) Serdang, Selangor Malaysia; ${ }^{2}$ Federal University Wukari, Taraba State, Nigeria $;{ }^{3}$ Modibbo Adama University of Technology Yola, Adamawa State, Nigeria.

Abstract | One of the strong mechanisms in the extension service delivery is the connection between agricultural
research, extension and the farmers. The evolving new model of agricultural production and the small number
of extension agents question old ways of providing valuable knowledge to farmers. The goal was to define
the respondents' socioeconomic characteristics, classify the types of ICT tools adopted by the respondents
and identify factors influencing the adoption of ICT in extension service delivery among the respondents.
Primary data were obtained using multi-stage cluster sampling technique, using organized questionnaires
administered to 254 respondents. Descriptive and inferential statistics was used. The research used Rogers'
Theory of Innovation Diffusion, Rogers and Burde's Theory of Social Change. The findings from the study
have shown that GSM, radio, television, camera, internet, computer, CD/DVD player and VHS video are
the most commonly used ICT components in various aspect of extension work. The multiple regression
results reveal that gender, age, level of education and working experience has no significant contribution to
ICT adoption while marital status, awareness, accessibility and motivation are the most influential factors
influencing the adoption of ICT's in extension service delivery. The study recommends that government
for support the extension organizations with the most commonly used ICT components, ensure adequate
awareness and access to ICT's. The government support and interest will motivate the extension agents to
adopt ICT's tools and technology in extension service delivery.
Received $\mid$ October 13, 2020; Accepted $\mid$ March 15,2021; Published $\mid$ November 30, 2021
'Correspondence $\mid$ Norsida Man, Universiti Putra Malaysia (UPM) Serdang, Selangor Malaysia; Email: norsida@upm.edu.my
Citation | Mustapha, S., N. Man, J.A. Shah, N.H. Kamarulzaman, A.A. Tafida. 2022. Factors influencing the adoption of ICT'S in extension
service delivery among the extension agents in North-East, Nigeria. Sarbad Journal of Agriculture, 38(1): 149-159.
DOI $\mid$ https://dx.doi.org/10.17582/journal.sja/2022/38.1.149.159
Keywords $\mid$ ICT, Adoption, Influencing, Extension agents, Northeast

\section{Introduction}

$\mathrm{D}$ issemination of knowledge and Technology are strategic goals for the successful agricultural extension (Zulqarmain et al., 2020; Aker, 2010). Different forms of information communication technologies (ICT) are used to disseminate agricultural information to farmers. Umar et al. (2015) stressed the role of technology in improving productivity in agriculture. The technology was seen as an important tool for agricultural production. Agricultural extension operations main focus is to provide adequate and valuable knowledge to reassure end-users to follow what will ultimately lead to the growth of agricultural production (Hassan et al., 2019; Ramli et al., 2019; Okunade and Oladosu, 2006).

The technology essentially means that information is applied to satisfy the goals, products and services that people want. It is the creation, modification 
or alteration of the natural environment to meet perceived human needs and desires (Ekwujuru, 2006; Umar et al., 2019; Man and Isah, 2019). There are significant regional gaps in the diffusion of Information and Communication Technology (ICT) referred to as "Global Digital Divide," which is a major concern for policymakers worldwide. The degree and speed of any technology's diffusion depend on the domestic ability to absorb advanced technologies, and this ability to absorb them differs across countries (between different countries). Meera et al. (2004), Ali et al. (2018) and Muktar et al. (2019) lamented that to disseminate knowledge or information packages, the agriculture extension must avoid the limited mindset of communicating technology packages. If this can be done, the extension could become more diversified, Use ICT's, more knowledge-intensive and demanddriven, and therefore more relevant in meeting the information needs of farmers.

To be successful in Nigeria in terms of agricultural extension, extension workers needs the requisite knowledge and skills to use modern ICTs while performing their job functions. The current communication gap between extension workers, on the one hand, and farmers, on the other, can be bridged by digital networking systems and ICTs (CTA, 2003). ICTs have the potential to increase the capacity of farmers to meet demands; collective learning; sharing time-sensitive information, such as market prices and outbreaks of diseases; improving the effectiveness of extension programmes and structures; involving farmers in assessing their own needs; promoting brainstorming by multiple stakeholders; creating innovative technologies for development; promoting business and credibility.

The importance of ICTs has long been recognized in the development process and access to ICTs has also been one of the objectives of Millennium Development Goal No. 8, which highlights the advantages of emerging technologies, particularly ICTs, in reducing poverty. The same study also noted that "connectivity-through the Internet or cell phones transfer business information rapidly; financial services and health services to remote areas and helping to change people's lives in unprecedented ways (Asenso-Okyere and Mekonnen, 2012; Umar et al., 2017; Saleh and Man, 2017; Ali et al., 2018) also reported that farmers received a variety of disaster management information from extension agents via ICT's.
The use of ICT in agricultural extension and rural development is important, especially now that its use has increased in many African countries in nearly all rural areas. However, the persistent issues of communication, literacy, quality and accessibility have continued to impede the widespread use of these facilities for agricultural knowledge. In this regard, Omotayo (2005) noted that agricultural extension depends to a large extent on the exchange of information between farmers and a wide range of other actors, in particular front-line extension staff, who are direct links between farmers and other actors in the Knowledge and Information System for Agriculture (AKIS).

ICT's role in agricultural expansion cannot be over-emphasized, but the sector still faces many challenges not only on African continents but also on another continent. For example, Azman et al. (2014) and Ali et al. (2018) lamented that lack of support from extension organizations in inadequate extension staff is part of the problem faced by Malaysia's extension service. Same scenario as reported by many authors facing extension organizations in Nigeria (Salau and Saingbe, 2008; Aker, 2010; Anderson and Feder, 2016; Anandajayasekeram et al., 2017).

The problems that this work aims to tackle are; the study area extension agents are insufficient to meet the demand of farmers. Haruna and Abdullahi (2013) recorded that as many as 4600 farmers in the study region are managed by one extension agent. According to Bell (2015), the number of extension staff is small, extension workers can lack sufficient knowledge and skills, and institutional motivation and resources to meet farmers demand. However, several writers (Anderson and Feder, 2016; Anandajayasekeram et al., 2017) reported that over the years, the Public Agricultural Extension Service has been working through a variety of methods, methodologies and programs to ensure that farmers have embraced improved technologies but have little success. This is because the extension service model implemented in the study area is an outdated extension service form. Salau and Saingbe (2008) argued that, in the face of evolving government policies and decreasing support, the use of traditional means of communication such as farm/home visits, personal letters and the use of farmers' contacts to disseminate agricultural information as enshrined in the $\mathrm{T}$ and $\mathrm{V}$ extension method is becoming less successful. According to FAO (2015) ICT can respond to a range of problems facing the 
frameworks of public extension.

Looking at the significance of ICT to agricultural extension and myriads of problems surrounding it, it becomes imperative to delve into the factors influencing the adoption of ICT in extension service delivery among the extension agents in north-eastern Nigeria and came up with a better-recommended policy that will help the system.

The objectives of this paper were to (1) measure socio-demographic characteristics of respondents (2) identify the adoption level of ICT components and (3) examine the factors influencing the adoption of ICT's among the respondents.

\section{Method of data collection and analysis}

The place of the study is Nigeria. Nigeria is made up of 36 states and the Federal Capital Territory, Abuja. The research was carried out in Nigeria (NorthEast). This is composed of six (6) states respectively; Adamawa, Bauchi, Borno, Gombe, Taraba, and Yobe. The area is situated between the latitude of 6o 20 'to $13 \mathrm{o} 00$ ' from the north and 9000 'to $14 \mathrm{o} 00$ ' east of the Greenwich Meridian. The region has an annual rainfall of between $700 \mathrm{~mm}$ and $1550 \mathrm{~mm}$ and three to six months of rainfall each year, with the wettest months being August and September, while February and March are the driest months with a relative humidity of around 13 percent (Adebayo and Umar, 1999). Farming is the area's main occupation, producing crops including beans, sesame, cassava, yam, rice, paddy, maize (corn), groundnuts, Arabic gum, millet, palm kernels, palm oil, rice, sorghum, soybeans, bananas, and yams (Verter, 2015).

The theoretical framework of this study (Figure 1) was based on Rogers' Diffusion of Innovation Theory (Rogers, 1962), which focuses on the adoption of Information and Communication Technologies. That indicates a major relationship between perception, socio-demographic factors and the adoption of ICTs. Rogers and Burde's theory (Rogers and Burde, 1972) of social change has also been found relevant in this study to explain how within a social system new innovations are implemented to achieve higher per capita income. And levelling by greater exposure to new methods of production and enhanced social organization. The research also contains the Organizational Support Theory (Rhodes and Eisenberger, 2002), which examines the relationship between perceived organizational support and performance of employees. In this study, the employee (extension) agents are expected to improve with the adoption of ICT in the provision of extension service.

Data for this research was collected from primary sources. The source of primary data was on the demographic information of the extension agents; the influence of ICT adoption which include the demographic factors, awareness, accessibility and perceived organizational support. A structured questionnaire was distributed to the participants, based on an interview schedule, to collect this information.

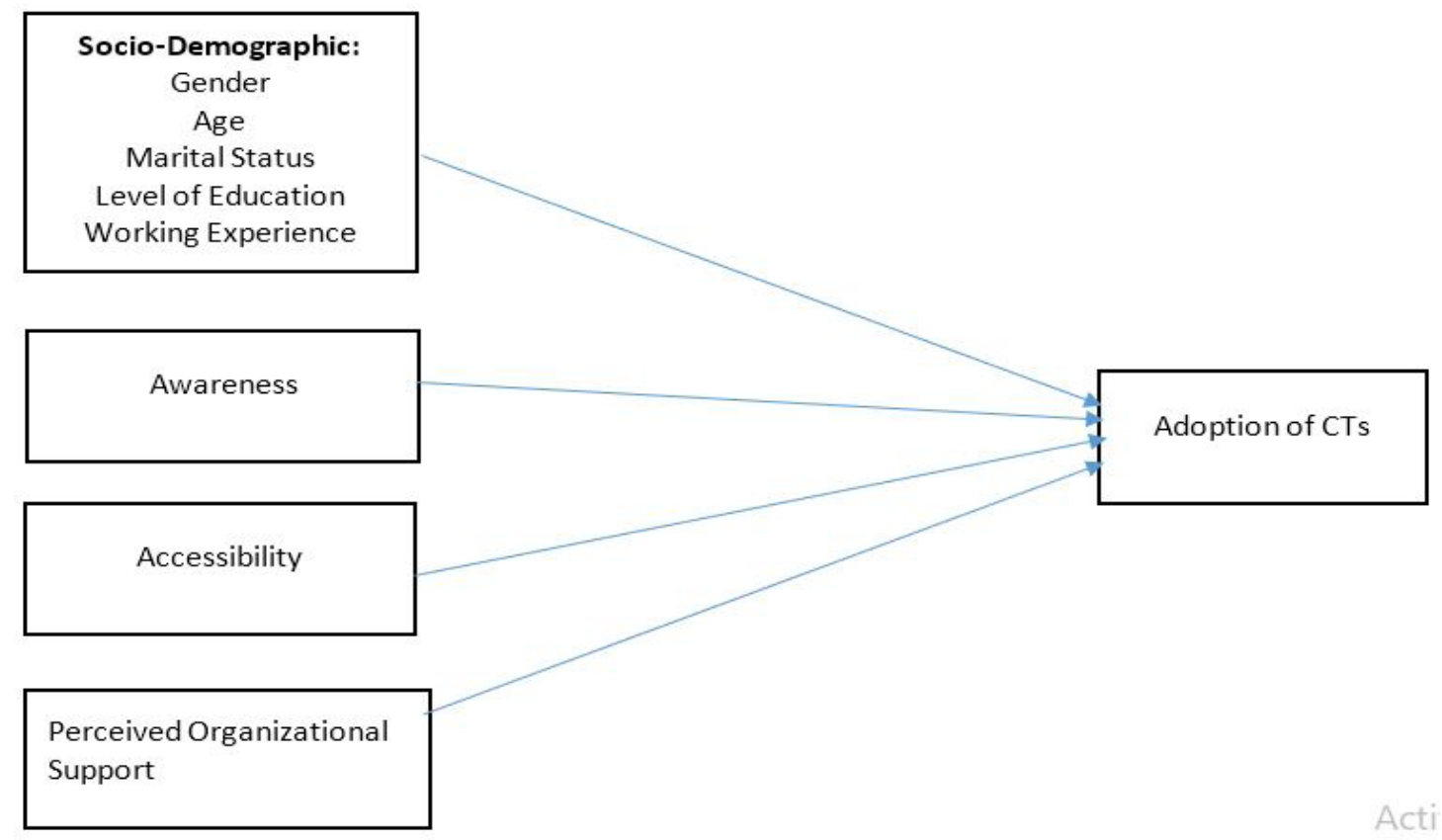

Figure 1: Conceptual framework. 
Table 1: Showing how the sample was proportionately arrived.

$\begin{array}{lllll}\text { States (population of EAs) } & \text { Sample states } & \text { Population of EAs } & \text { Procedures } & \text { Sample } \\ \text { 1. Adamawa (138) } & \text { 1. Adamawa } & 138 & \begin{array}{l}138 / 407=0.339 \\ 0.339 \times 254=86.12\end{array} & 86 \\ & & & \\ \text { 2. Bauchi (114) } & & 116 / 407=0.285 & 72 \\ \text { 3. Borno (124) } & & 0.285 \times 254=72.39 & \\ \text { 4. Gombe (116) } & \text { 4. Gombe } & 116 & 153 / 407=0.375 & 95 \\ \text { 5. Taraba (153) } & \text { 5.Taraba } & 153 & 0.375 \times 254=95.48 & \\ & & & & 254\end{array}$

(Pallant, 2010).

\section{Normal P-P Plot of Regression Standardized Residual}

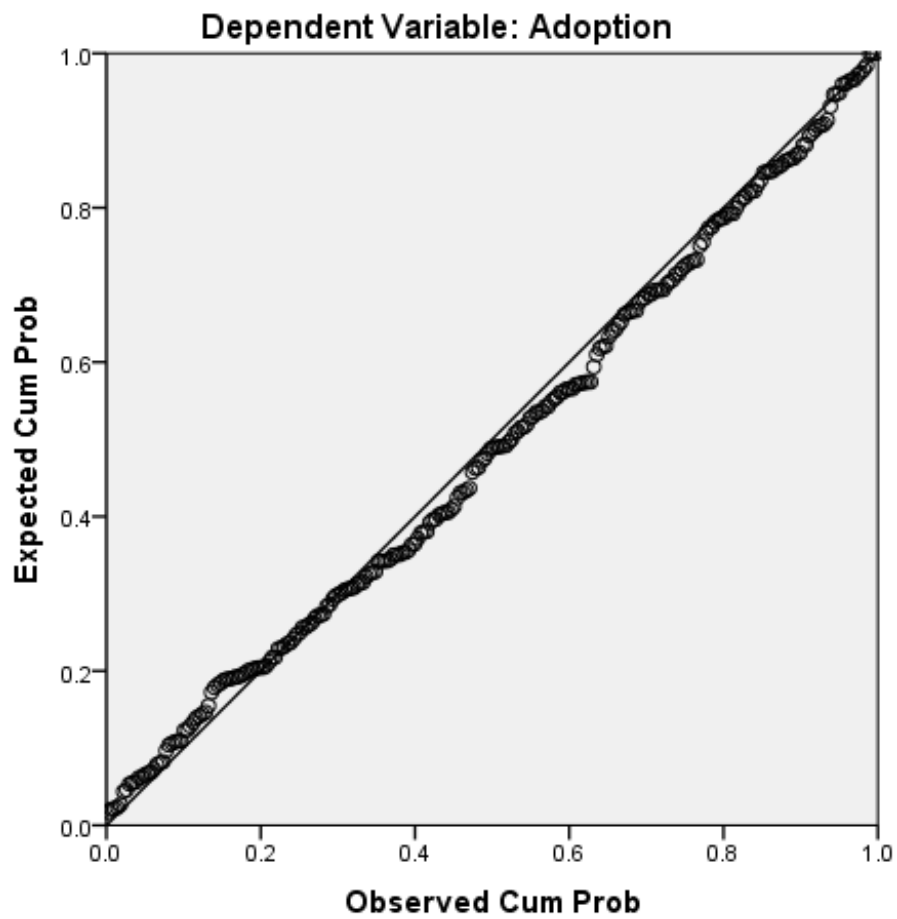

Figure 2: The sampling procedure (multi-stage).

This study adopts and uses a combination of techniques as a sampling procedure (Table 1 and Figure 2). The researchers used a multi-stage cluster sampling and stratify sampling procedures to select the sample for the study. In the first stage, from the existing six (6) states that make up the North-East zone of Nigeria, which serve as the population of the study with a total number of 751 extension agents, three states were randomly selected (Adamawa, Gombe and Taraba) and the sample was drawn from them, the 3 states has a total population of 407 extension agents (Adamawa 138, Gombe 116 and Taraba 153). From which 254 respondents were selected for this study.

\section{Analytical technique}

Descriptive and inferential statistics including mean, frequency percentage, were used for analysis. The descriptive statistics were used to define the socioeconomic characteristics of the respondents, to classify the types of ICT components they adopted while multiple regression (inferential statistics) was used to examine the factors influencing the adoption of ICT's in extension service delivery among the respondents.

Descriptive Statistics such as frequency distribution, means, and percentages were used to characterize the respondents' demographic profile and classify the types of ICT components that the respondents adopted. The mean is translated as:

$$
\bar{X}=\Sigma f x / n
$$

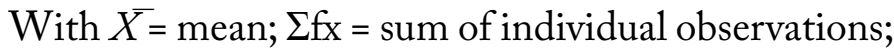
$\mathrm{n}$ = sample size; Multiple regression analysis was used to examine the factors influencing the adoption of ICT's in extension service delivery among the respondents in the study area.

\section{Model specification}

$Y=b_{0}+b_{7} x_{1}+b_{2} x_{2}+b_{3} x_{3}+b_{4} x_{4}+b_{5} x_{5}+b_{6} x_{6}+b_{7} x_{7}+b_{8} x_{8}+u$ Where; Y= ICT adoption; $\mathrm{x}_{1}=$ Age of respondent; $\mathrm{x}_{2}=$ Level of education; $\mathrm{x}_{3}=$ House hold size; $\mathrm{x}_{4}=$ Years of working experience; $\mathrm{x}_{5}=$ income; $\mathrm{x}_{6}=$ awareness; $\mathrm{x}_{7}=$ accessibility; $\mathrm{x}_{8}=$ perceived organizational support; $\mathrm{x}_{9}$ $=$ motivation; $\mathrm{u}=$ Error term .

\section{Diagnostic test results of the multiple regression}

Multi collinearity refers to the high degree of relationship existing between independent variables (Field, 2001). The correlation table obtained 
from regression output (Table 2) show that these assumptions were not violated in the model. Furthermore, collinearity statistics (Tolerance and Variance Inflation Factor) generated in the output showed the Tolerance values ranging between 0.307 and 0.911 each above the minimum of 0.10 . Likewise, the variance inflation factor (VIF) ranged between 1.098 and 3.258, each far below the maximum of 10 (Pallant, 2011)

Table 2: Multi collinearity results.

$\begin{array}{lll}\text { Variable } & \text { Tolerance } & \text { VIF } \\ \text { Accessibility } & .307 & 3.258 \\ \text { POS } & .349 & 2.862 \\ \text { Awareness } & .397 & 2.521 \\ \text { Motivation } & .380 & 2.630 \\ \text { Age } & .899 & 1.112 \\ \text { Gender } & .952 & 1.050 \\ \text { M. Status } & .903 & 1.107 \\ \text { W. Exp } & .969 & 1.032 \\ \text { Educ } & .911 & 1.098\end{array}$

The normality test conducted has shown that the data are little skewed and kurtotic, for the variables (Gender, age, marital status, Level of education, working experience, awareness, accessibility, perceived organizational support and motivation) but it did not differ significantly for normality. We can assume that the data is approximately normally distributed, in terms of skewness and kurtosis. Table 3 explain the results.

Table 3: Normality of the variables:

$\begin{array}{lll}\text { Variable } & \text { Skewness } & \text { Kurtosis } \\ \text { Accessibility } & -.613 & .182 \\ \text { POS } & .734 & .133 \\ \text { Awareness } & .014 & -.351 \\ \text { Motivation } & -.311 & -.432 \\ \text { Age } & .104 & -.192 \\ \text { Gender } & -.533 & .232 \\ \text { MStatus } & -.466 & -.332 \\ \text { WExp } & -.151 & .018 \\ \text { Educ } & .104 & -.194\end{array}$

The normal pp plot shown in Figure 2 seems to show a diagonal straight-line indicating absence of outliers (Pallant, 2011). Furthermore, the probabilities for the Mahalanobis distance was calculated using SPSS function, none of the probabilities was found to be lower than 0.001 , indicating absence of multivariate outliers in the model.

\section{Normal P-P Plot of Regression Standardized Residual}

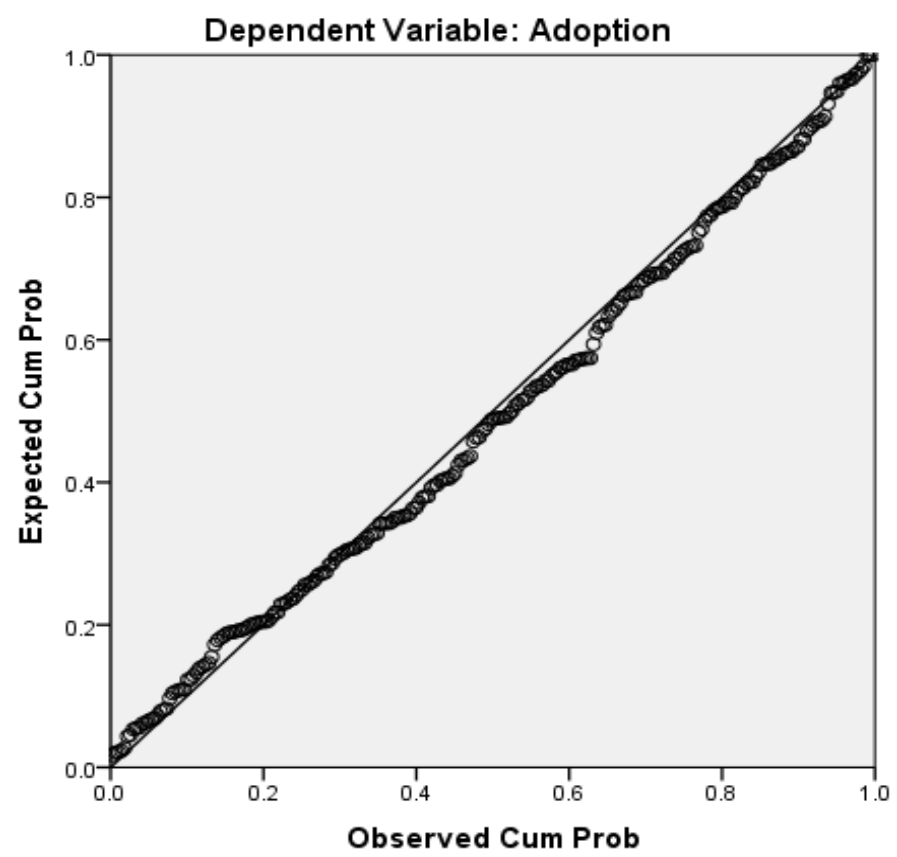

Figure 3: Normal $p$-p plot of standardized regression residual.

The scatterplot of the residuals obtained at the end of the regression output explained the assumption of linearity, Heterodasticity, independence of residuals and normality (Pallant, 2011). The point of ZRESID and ZPRED plot are "randomly and evenly dispersed". More or less in the rectangular shape. This indicates that the residual has a linear relationship with the predicted outcome variable scores (Linearity) and that for all the predicted scores. The variance of the residuals is the same (homoscedacity). The opposite is heteroscedasticity ("different scatter"), where points are at widely varying distances from the regression line. Figures 3 and 4 explain the scenario.

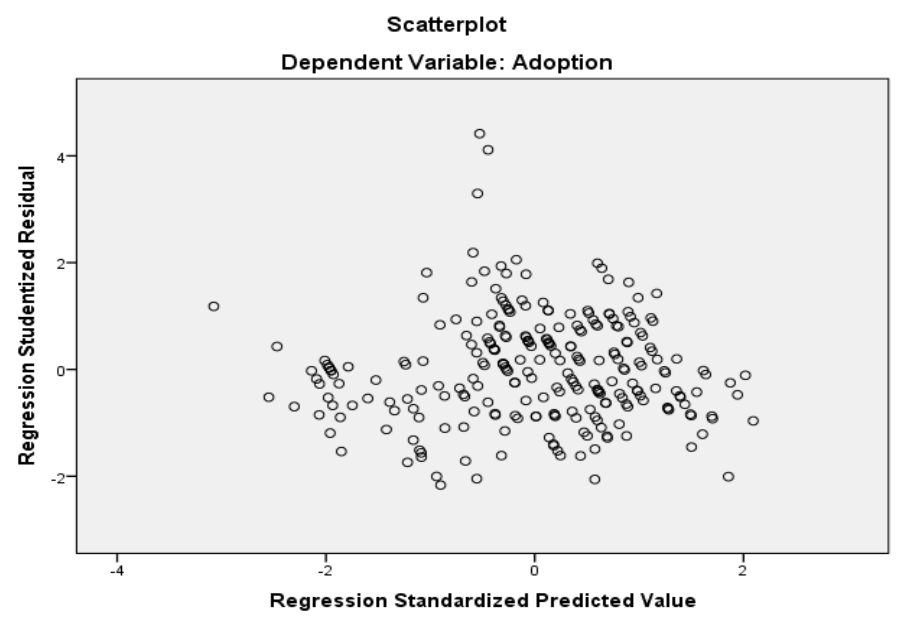

Figure 4: Normal $p-p$ plot of standardized regression predicted value. 


\section{Results and Discussion}

The result from Table 4 shows that most of the extension agents (92.1 percent) were male while 7.9 percent were female. The respondent's age distribution indicated that the majority of respondents (77.1 per cent) were between the ages of 31-50. Those who were within the age range of 21-30 years and 50 years above respectively represented $13.8 \%$ and $16.3 \%$. The respondents' median age was 41 years. Agricultural extension agents' marital status indicates that the majority $(85.8 \%)$ of agricultural extension agents were married, $5.5 \%$ divorced single $4.7 \%$ and 3.9 percent were widowed. Approximately 54.7\% and $41.7 \%$ of agricultural extension agents had Nigeria certificates in Education (NCE)/Ordinary National Diploma (OND) and Higher National Diploma (HND), respectively, 3.5\% had Bachelor degrees, non with Masters degrees or $\mathrm{PhD}$ Majority (50.4\% of respondents had 15 to 23 years of work experience, $3.5 \%$ of respondents had less than 2 years of work experience, $3.5 \%$ had 3 to 6 years of work experience and $35 \%$ of respondents had 7 to 10 years of extension work, while $5.5 \%$ had 11 to 14 years of work experience.

\section{ICT components adopted by respondents}

To identify the type of ICT components adopted by the respondents, descriptive analysis using frequency and percentages was employed. Based on the findings of this study it reveals that $92.51 \%$ of the extension agents adopted GSM phones in extension work, only $7.48 \%$ did not adopt. On the adoption of Radio in extension work about $98.81 \%$ has adopted while $1.18 \%$ did not adopt. Also, $72.44 \%$ has adopted television while $27.55 \%$ did not adopt. Also, $37 \%$ has adopted cinema and majority (62.99\%) did not adopt cinema in extension work, $58.66 \%$ has adopted the use of the internet in extension work and $42.33 \%$ did not adopt.

On the use of computer in extension work $59.84 \%$ has adopted while 40.15 did not adopt. On the use of an overhead projector, $35.03 \%$ has adopted while $64.96 \%$ did not adopt. $42.91 \%$ has adopted the use of cassette recorder in extension work and 57.08\% did not adopt. Furthermore, the study reveals that 48.81\% has adopted pocket devices in extension work while $51.18 \%$ did not adopt. $24.40 \%$ adopted GIS (Geographic Information System) in extension and $75.59 \%$ did not adopt. Similarly, the majority
(68.50\%) adopt the use of CD/DVD Player in extension work and $31.49 \%$ did not adopt. Finally, $55.11 \%$ has adopted the use of VHS Video Player in extension work and $44.88 \%$ did not adopt as presented in Table 5. From the research results it shows that all of the extension agents in the study area have taken one type or the other of the ICT components. The result is consistent with the findings of Man and Isa (2019), Ali et al. (2018), Umar et al. (2015), Dire et al. (2016), Azman et al. (2014) and Yakubu et al. (2013).

Table 4: Respondents' characteristics.

\begin{tabular}{|c|c|c|}
\hline Respondents characteristics & Frequency & Percentage \\
\hline \multicolumn{3}{|l|}{ Gender } \\
\hline Male & 234 & 92.1 \\
\hline Female & 20 & 7.9 \\
\hline Total & 254 & 100 \\
\hline \multicolumn{3}{|l|}{ Age } \\
\hline $21-30$ & 35 & 13.8 \\
\hline $31-40$ & 65 & 25.5 \\
\hline $41-50$ & 131 & 51.6 \\
\hline $51-60$ & 21 & 8.3 \\
\hline 61 above & 2 & .8 \\
\hline Total & 254 & 100 \\
\hline \multicolumn{3}{|l|}{ Marital status } \\
\hline Married & 218 & 85.8 \\
\hline Single & 14 & 5.5 \\
\hline Divorced & 12 & 4.7 \\
\hline Widowed & 10 & 3.9 \\
\hline Total & 254 & 100 \\
\hline \multicolumn{3}{|l|}{ Level of education } \\
\hline NCE, OND & 139 & 54.7 \\
\hline HND & 106 & 41.7 \\
\hline $\mathrm{B}, \mathrm{Sc}$ & 9 & 3.5 \\
\hline Total & 254 & 100 \\
\hline \multicolumn{3}{|l|}{ Working experience } \\
\hline$<2$ years & 9 & 3.5 \\
\hline $3-6$ years & 14 & 5.5 \\
\hline $7-10$ years & 89 & 35.0 \\
\hline $11-14$ years & 14 & 5.5 \\
\hline $15-18$ years & 39 & 15.4 \\
\hline $19-22$ years & 44 & 17.3 \\
\hline 23 years and above & 45 & 17.7 \\
\hline Total & 254 & 100 \\
\hline
\end{tabular}
March 2022 | Volume 38 | Issue 1 | Page 154 
Table 5: Type of ICT tools.

\begin{tabular}{lll} 
ICT Components & $\begin{array}{l}\text { Not adopted } \\
\text { Frequency (\%) }\end{array}$ & $\begin{array}{l}\text { Adopted } \\
\text { Frequency (\%) }\end{array}$ \\
\hline GSM Phones & $19(7.48)$ & $235(92.51)$ \\
Radio & $3(1.18)$ & $251(98.81)$ \\
Television & $70(27.55)$ & $184(72.44)$ \\
Cinema & $160(62.99)$ & $92(36.22)$ \\
Camera & $84(33.07)$ & $170(66.92)$ \\
Internet & $105(41.33)$ & $149(58.66)$ \\
Computer & $102(40.15)$ & $152(59.84)$ \\
Overhead Projector & $165(64.96)$ & $89(35.03)$ \\
Cassette Recorder & $145(57.08)$ & $109(42.91)$ \\
Pocket Devices (PDAs) & $130(51.18)$ & $124(48.81)$ \\
GIS (Geographic & $192(75.59)$ & $62(24.40)$ \\
Information System) & & \\
CD/DVD Player & $80(31.49)$ & $174(68.50)$ \\
VHS Video Player & $114(44.88)$ & $140(55.11)$
\end{tabular}

Regression results on factors influencing the adoption of ICT's in extension service delivery

The analysis determined the relationship between the dependent variable and the independent variables. The dependent variable " $\mathrm{Y}$ " is the ICT adoption while the independent variables " $\mathrm{X}$ " are the gender, age, and marital status, level of education, working experience, awareness, accessibility, perceived organizational support and motivation.

Four functional forms were tried and based on the econometric and statistical criterion, Linear equation was chosen as the lead equation and the results are presented in Table $6 \mathrm{R}^{2}$ showed that $90.90 \%$ of the variation in $\mathrm{Y}$ (ICT adoption) was explained by the explanatory variables " $\mathrm{X}_{1}-\mathrm{X}_{9}$ " (gender, age, marital status, level of education, working experience, awareness, accessibility, perceived organizational support and motivation.). F-ratio is significant at $1 \%$ meaning that the model is adequate in explaining the probability of explanatory variables on the influence of ICT adoption (Y).

Based on the findings of this study it reveals that gender, age, level of education and working experience has no significant contribution to ICT adoption in extension work by the extension agents in northeast Nigeria. This is because all the extension agents possess the basic pre-requisite professional qualification to work as extension agents and this does not make any difference in class, age, educational level and work experience as regards their decision to implement
ICT tools in extension work. This is consistent with this finding (Dire et al., 2016; Yakuba et al., 2013; Umar et al., 2015; Yekinni and Hussein, 2008; Salau and Saingbe, 2008; Otolo, 2008). Marital status is significant at $1 \%$ with positive coefficient meaning that marital status has a significant contribution to ICT adoption by extension agents, this is because married people were expected to be rational thinkers and responsible in decision making. According to Yakubu et al. (2013) married agricultural extension agents in the area are responsible and can be valued, trusted and committed to their duties, particularly as regards the genius of the information they would provide during their extension work. The findings corroborate with (Muhammad et al., 2020; Mohammed et al., 2016; Umar et al., 2017; Abraham, 2007) who found that demographic variables like gender have a significant influence on ICT adoption among the extension agents in the study area.

Table 6: Multiple regression results on factors influencing the adoption of ICT.

$\begin{array}{llll}\text { Variables } & \text { B } & \text { S.E } & \text { P-value } \\ \text { Gender } & .235 & .410 & .567 \\ \text { Age } & .012 & .013 & .345 \\ \text { Marital status } & .776 & .156 & .000^{* *} \\ \text { Level of education } & -.377 & .203 & .064 \\ \text { Working experience } & -.120 & .062 & .055 \\ \text { Awareness } & .664 & .027 & .000^{* *} \\ \text { Accessibility } & .264 & .041 & .000^{* *} \\ \text { Passive org. support } & -.117 & .033 & .001^{* *} \\ \text { Motivation } & .040 & .017 & .022^{*}\end{array}$

*** Significant $(p<0.01) ; *$ Significant $(p<0.05)$.

From the results of multiple regression analysis, awareness is significant at $1 \%$ with a positive coefficient, meaning that awareness has a significant contribution on ICT adoption, it signifies that the more extension agents get to know of the ICT tools in extension work the more they accept such technology. Adequate knowledge of any given invention or technology is key to the success of the technology being implemented and used. The findings are in line with Mukhtar et al. (2019); Adesope et al. (2007), Abraham (2007) and Adesope and Matthews (2007). This is also in line with Rogers (1962) diffusion of innovation theory which reiterates that knowledge on ICT's leads to the adoption of such technology. 
Accessibility is also significant at $1 \%$ with a positive coefficient, meaning that the more the extension agents have access to ICT tools they more they adopt them in extension work. The findings imply that accessibility has a significant contribution to ICT adoption among the extension agents in northeastern Nigeria. Agricultural extension officers are the direct link that bridges the communication gap between agricultural researchers and farmers to carry out this role effectively and efficiently, agricultural extension staff must have steady access to ICT instruments for up to date of agricultural information which will enable them to adopt ICT's in extension work (Ramli et at., 2019; Umar et al., 2015).

Perceived organizational support is significant at $1 \%$ with negative coefficient meaning perceived organizational did not influence ICT adoption by the extension agent. This could be as a result of the absence of motivation because many researchers have found a strong mediating role of motivation between perceived organizational support and employee performance, in this context it refers to the performance of extension agent in their organization when they adopt ICT in extension work. Umar et al., 2017, 2019; Saleh and Man (2017); Eisenberger et al. (1986) identifies a correlation in an exchange relationship between employee expectations, incentives and the employee's loyalty to the organization, suggesting that there is an expectation of compensation. The reward needn't be immediately material or received. The reward can be affirmation, effort support and the perception that they have successfully performed or performed consistently within the expectations of the culture of the organization. With this reward, there is a greater motivation for the employees to meet the goals of the organization. At the same time, this encouragement fosters participation as leaders become more associated with the aims of the group, making the aims of the organizations their own.

The results of the multiple regression analysis revealed that four variables contributed significantly to ICT adoption in extension work. It shows the following beta value of variables; marital status $(\beta=.777$, $\mathrm{p}=.000)$, awareness $(\beta=.664, \mathrm{p}=.000)$, accessibility $(\beta=.264, p=.000)$, motivation $(\beta=.040, p=.022)$. The results of the multiple regression model indicated the significance of the four variables. Marital status has the highest value $(\beta=0.777)$. This was in consistency with (Mukhtar et al., 2019; Salau and Saingbe, 2008;
Dire et al., 2016; Umar et al., 2015; Yakuba et al., 2013; Yekinni and Hussein, 2008; Otolo, 2008; Abraham, 2007).

\section{Conclusions and Recommendations}

The study was carried out to unveil the current status of ICT adoption and the most influencing factors that determine the adoption of ICT's among the extension agents in the study area. The extension work appears to be male dominated activity, this is because of the cultural and religious attachment to it where extension work was seen as the men occupation in the study area, and this discourages women from participating in extension work. In respect to ICT adoption in; GSM, radio, television, camera, internet, computer, CD/DVD player and VHS video are the most commonly used ICT component that connects the extension agents with agricultural information, this will replace the old methods of extension delivery and pave ways for the effective channel that will cover the inadequacy of extension personal in the study area. Also due to the homogeneity of extension agents, their no difference of gender, age, level of education, working experience and perceived organizational support when it comes to ICT adoption. Similarly, marital status, awareness, accessibility and motivation are among the reasons that the extension agents adopt the current ICT components in the study area. And that will fasten the timely delivery and up to date information of extension messages.

The extension work appears to be male dominated activity in the study area, female extensionist should be recruited to pave way for gender equality in extension work, this will encourage women farmers to venture actively in to farming; GSM, radio, television, camera, internet, computer, CD/DVD player and VHS video are the most commonly used ICT component, government and donor agencies were encouraged to make those gargets available to the extension personnel. Marital status, awareness, accessibility and motivation are very important factors in influencing ICT adoption in extension service delivery among the extension agents in the study area. Hence, it is recommended that government should design a policy framework that will encourage the recruitment of married people in extension work and as well pave ways for the extension workers to have access to ICT's. More awareness should be encouraging among the extension workers on the need to embrace ICT's 
in extension work. Extension organizations should be mindful of the motivation levels of their employee, such could facilitate the adoption of ICT in extension work which will facilitate timely delivery of extension messages, cover the man power shortages, safe cost and total transformation of agricultural development in the area.

\section{Novelty Statement}

This research identifies the most available ICT components available to the extension agents and the influencing factors to their adoption. The findings will lead the way in solving the problems that threatened the connection of the extension agents with agricultural information.

\section{Author's Contribution}

Sa'adu Mustapha: Conceived, designed, coordinated data collection, data analysis and writing the draft manuscript.

Norsida Man: Contributed in designing of the instrument and supervise the research process.

Jasmin Arif Shah: Contributed in data analysis and edit work of the manuscript.

Nitty Hirawaty Kamarulzaman: Contributed in validating the instruments, research framework and supervision.

Ahmadu Abubakar Tafida: Contributed in the data collection and interpretation.

\section{Conflict of interest}

The authors have declared no conflict of interest.

\section{References}

Abraham, R., 2007. Mobile Phones and Economic Development: Evidence from the Fishing Industry in India. J. ICT., 4(1): 5-17. https:// doi.org/10.1162/itid.2007.4.1.5

Adebayo, A.A. and A.S. Umar. 1999. Hydrology and Water Resources. p.101-123. In: Adebayo, A. A. and Tukur, A.L. (eds.) Adamawa State in Maps. Paraclete Publishers, Yola Nigeria.

Adesope, O.M. and N. Matthews. 2007. Perceived Effect of Information Technology on agricultural Research among Agriculturists in Nigerian Tertiary Institutions. Proc. Agric. Ext. Soc. Nigeria (AESON) 10 th Ann. Conf. Ilorin, Nigeria, 10: 96-101.
Aker, J.C. and I. Mbiti. 2010. Mobile phones and economic development in Africa. J. Econ. Precative, 24(3): 207-232. https://doi. org/10.1257/jep.24.3.207

Ali, M., N. Man, A. Latif, F.M. Muharram and S.Z. Omar. 2018. The use of information and communication technologies in agricultural risk management by the agricultural extension services in Malaysia. Int. J. Agric. Environ. Food Sci. 2(1): 29-35. https://doi.org/10.31015/ jaefs. 18005

Anandajayasekeram, P., R. Puskur, S. Workneh and D. Hoekstra. 2017. Concepts and practices in agricultural extension in developing countries: A source book. IFPRI (International Food Policy Research Institute), Washington, DC, USA, and ILRI (International Livestock Research Institute), Nairobi, Kenya. pp. 275.

Anderson, J.R. and Feder, G., 2016. Agricultural extension: Good intentions and hard realities. The World Bank Research Observer

Asenso-Okyere, K. and D.A. Mekonnen. 2012. The importance of ICTs in the provision of information for improving agricultural Productivity and rural incomes in Africa. Working Paper. UNDP. pp. 30.

Azman, A., J.L. D’Silva, B.A. Samah, M. Norsida and H.A.M. Shaffril. 2014. Relationship between attitude, knowledge, and support towards the acceptance of sustainable agriculture among contract farmers in Malaysia. Asian Soc. Sci., 9(2): 99-105. https://doi.org/10.5539/ass. v9n2p99

Bell, M., 2015. Powering behavior change for a brighter agricultural future. MEAS Discussion Paper, University of California

Centre for Agricultural and Rural Cooperation, (CTA) 2003. ICTs transforming agricultural extension? An e-discussion held $20^{\text {th }}$ August, 29th Sept. 2003 Edition.

Dire, B., J.I. Onu, A.A.U. Jungur, A.A. Ndaghu and D.Y. Giroh. 2016. Awareness on the use of information and communication technologies (Icts) among agricultural extension agents. North-East. Nigeria Sci. Pap. Ser. Manage. Econ. Eng. Agric. Rural Dev., 16(1): 22847995.

Eisenberger, R., R. Huntington, S. Hutchison and D. Sowa. 1986. Perceived organizational. Support. J. Appl. Psychol., 71(3): 500-507. https://doi.org/10.1037/0021-9010.71.3.500 
Ekwujuru, T.N., 2006. Advantages of ICT knowledge and its application in philosophical research in Education. In: Ezeh, D.N. and Nkadi Onyegegbu (eds) ICT in the service of education. Institute of Education, UNN. TIMEX. Enugu.

Field, A., 2001. Discovering statistics using SPSS $\left(3^{\text {rd }}\right.$ ed) London: Sage.

Food and Agriculture Organization of the United Nations (FAO). 2015. Success stories on information and communication technologies for rural development. RAP Publication 2015/02. Bangkok, Thailand: FAO Regional Office for Asia and the Pacific

Haruna, S.K. and Y.M.G.Abdullahi.2013.Training of public extension agents in Nigeria and the implications for Government's agricultural transformation agenda. J. Agric. Ext., 17(2): ISSN 1119-944X: https://doi.org/10.4314/jae. v17i2.13

Hassan, S., M. Galadima, N. Man and I. Abu. 2019. Exploring farmers attitude, practice and relationship with adoption of improved pearl millet technology in North-Eastern Nigeria. Int. J. Sci. Technol. Res., 8(9): 1098-1105.

Man, N. and S.N. Isah. 2019. The influence of attitude, social norms on adaptation practices of oil palm smallholders, and mediation role of intention towards climate change impact in Malaysia. Int. J. Sci. Technol. Res., pp. 9.

Meera, S.N., A. Jhamtani and D.U.M. Rao. 2004. Information and communication technology in agricultural development: A comparative analysis of three projects from India. Agric. Res. Ext. Netw. Network Paper No. 135, (13pp) June 2012.

Mohammed, S.J., N.Man and M.J.H.Al-Hamdany. 2016. Methodology: Training requirement of agriculture extension officers in Iraq. Am. Eurasian J. Agric. Environ. Sci., 16(1): 60-69.

Muhammad A., N. Man and M.M. Farrah. 2020. Intention level of farmers to use information communication technologies for agricultural risk management in Malaysia. J. Int. Agric. Ext. Educ., 27(2). https://doi.org/10.5191/ jiaee.2020.272108

Muktar, B.G., N. Man, J.M. Saleh and M.I. Daneji. 2019. Evaluation of ICTs access, use and preferences for livelihood resilience: Results from a survey of Malaysian fisher folks. J. Agric. Educ. Ext., 24(4): 377-388. https://doi.org/10.
1080/1389224X.2018.1479279

Okunade, E.O. and I.O. Oladosu. 2006. Rating of extension teaching methods for training female farmers in Osun state, Nigeria. Proc. $10^{\text {th }}$ Ann. Conf. Agric. Ext. Soc. Nigeria.

Omotayo, O.M., 2005. ICT and agricultural extension: Emerging issues in transferring agricultural technology in developing countries. Adedoyin S.F. (Ed) Agricultural Extension in Nigeria, AESON, pp. 145-158.

Otolo, P.U., 2008. The impact of information and communication in extension services to rural farmers in Niger Delta. Inf. Technol., 5(2): 3642. https://doi.org/10.4314/ict.v5i2.32025

Pallant, J., 2011. SPPS survival manual: A step by step guide to data analysis using IBM SPSS (2011 ${ }^{\text {th }}$ ed.). Australia: Allen and Unwin.

Ramli, N.S., N. Man, M.S. Hassan, A.S. Bahaman, S.Z. Omar, Y. Sarina, N.A.A Rahman and M.S. Ibrahim. 2019. Pattern of mobile phone usage among paddy farmers. Int. J. Acad. Res. Bus. Soc. Sci., 9(12). https://doi.org/10.6007/ IJARBSS/v9-i6/5969

Rhoades, L. and R. Eisenberger. 2002. Perceived organizational support: a review of the literature. J. Appl. Psychol., 87: 698-714.

Rogers, E.M. 1962. Diffusion of innovations. New York: Free Press.

Rogers, M.E. and J.R. Burdges. 1972. Social change in rural societies (Second Edition). PrenticeHall, Inc., Eaglewood Cliffs, New Jersey, U.S.A.

Salau, E.S. and N.D Saingbe. 2008. Access and utilization of ICTs among Agricultural Researchers and Extension workers in selected institutions in Nassarawa State of Nigeria. 1(6). http://patnsukjournal.net/vol4No2/pl.pdf

Saleh, J.M. and N. Man. 2017. Training requirements of agricultural extension officers using borich needs assessment model. J. Agric. Food Inf., 18(2): 110-122. https://doi.org/10.1 080/10496505.2017.1281748

Umar, S., N. Man, N.M. Nawi, 1.A. Latif and B.A. Samah. 2017. Core competency requirements among extension workers in peninsular Malaysia: Use of Borich's needs assessment model. Eval. Program Plann., 62(9): 14. https:// doi.org/10.1016/j.evalprogplan.2017.02.001

Umar, S., N. Man, N.M. Nawi, A. Ismail and B.G. Mukhtar. 2019. Underlying structure of job competency scale in climate- smart agricultural extension service. Pertanika J. Soc. Sci. Hum., 
27(1): 93-111.

Umar, S., W. Michael, Y. Musa, O. Toluwase and S. Rabiu. 2015. Awareness and use of information and communication technologies among extension agents in Kaduna State of Nigeria. J. Agric. Ext. Ser., 19(1). https://doi.org/10.4314/ jae.v19i1.6

Verter, N. 2015. An analysis of yam production in Nigeria. Acta Universitatis Agriculture et Silviculturae Mendelianae Brunensis. 63: 659-665. https://doi.org/10.11118/account 201563020659

Wirsiy, K.C. and R.M. Shafack. 2002. The impact of information technology on information dissemination. In: Madu, E.C. and Dirisu, M.B. (eds). Information science and technology for school library in Africa. Ibadan: Evicoleman. pp. 86-93.

Yakubu, D.H., A.B. Abubakar, T.K. Atala and A.
Muhammed. 2013. Use of information and communication technologies among extension agents in Kano State, Nigeria. J. Agric. Ext., 17(1): 162-173. https://doi.org/10.4314/jae. v17i1.16

Yekinni, O.T., L.A. Hussein. 2008. An assessment of the relevance of information and communication technologies (ICTs) to agricultural and rural development by research and extension personnel in South-Western Nigeria. Nigerian J. Rural Soc., 8(1): 76-82.

Zulqarnain, I., N. Man, S.Juwaidah, R. Muhammad and H. Salim. 2020. Factors influencing attitude towards technology adoption among permanent food production park (PFPP) program participants in west Malaysia. J. Agric. Sci. Technol., B10(2020): 89-97. https://doi. org/10.17265/2161-6264/2020.02.004 